\title{
An Explanation of Federal Reserve Actions (1933-68)*
}

I shift in professional opinion with respect to the impact of Federal Reserve actions on national income. More economists now acknowledge that these actions play a key short-run role in the determination of total demand. Monetary studies, using United States as well as foreign data, have given considerable support to this position. ${ }^{1}$ Parallel with the increased recognition of Federal Reserve actions as an important determinant of national income has been an escalation of the controversy over the proper interpretation of monetary policy. For example, the financial press has at times expressed concern that restrictive policy statements are not always followed by restrictive actions.

This public controversy about the alleged discrepancy between some monetary policy statements and Federal Reserve actions is based upon a fundamental controversy within the economics profession over the proper measure of Federal Reserve actions. Economists of a neo-Keynesian persuasion believe that Federal Reserve actions have their primary effect on the economy through changes in interest rates. According to this view, high or rising interest rates indicate restrictive monetary influences on the economy, while low or falling interest rates indicate easy monetary influences. By this measure the Federal Reserve has almost always followed appropriate countercyclical

\footnotetext{
The authors give special thanks for helpful comments on earlier drafts to: Leonall Andersen, Karl Brunner, David Fand, Harry Johnson, Allan Meltzer, David Rowan and William Yohe. The authors are solely responsible for any remaining errors.

1For exanple, see "Monetary and Fiscal Actions: A Test of Their Relative Importance in Economic Stabilization" by Leonall C. Andersen and Jerry L. Jordan, available as Reprint No. 34 and taken from the November 1968 issue of this Review. Also see Milton Friedman, et al., Varieties of Monetary Experience (Chicago: University of Chicago Press, 1969), and Michael W. Keran, "Monetary Policy and the Business Cycle - The Foreign Experience," this Review, November 1967. In the neo-Keynesian tradition, the MITFRB model also shows the strong impact of monetary actions.
}

stabilization policies. Interest rates have generally been rising when the Federal Reserve called for tight money, and falling when it oalled for easy money.

Economists who consider that the Federal Reserve has its primary effeot on the economy through changes in monetary aggregates, such as the money stock or the monetary base, consider that an accelerating aggregate is a sign of expansionary monetary influences on the economy and a decelerating aggregate is a sign of restrictive monetary influences. On the basis of aggregate measures, Federal Reserve actions have been criticized for not always being consistent with stated monetary policy.

The intent of this article is to examine the reasons Federal Reserve actions, as measured by monetary aggregates, have not always been consistent with stated monetary policy. This discrepancy is largely explained by the fact that while monetary policy is typically stated in terms of attempting to stabilize income, employment, prices and the balance of payments around some desired level or growth rate, Federal Reserve actions are actually responsive to a wider set of objectives. As the "bank of last resort", the Federal Reserve has a responsibility to insure the institutional viability of the nation's financial system. As the fiscal agent of the Federal Government, the Federal Reserve has a responsibility for insuring a receptive market for Treasury issues of new debt. When these other objectives are added to the stabilization objectives, we have a more complete view of Federal Reserve actions and an explanation for the observed discrepancies between monetary policy statements which are related to stabilization objectives and actual Federal Reserve actions.

In the following sections indexes will be constructed to represent the Federal Reserve's stabilization and other objectives. Building on these indexes, evidence is presented showing that for the past 36 years the Federal Reserve has acted in a consistent manner with respect to these objectives. 


\section{Measuring Monetary Policy or Stabilization Objectives}

Monetary policy is defined in this article as the Federal Reserve's response to stabilization goals, that is, achieving target levels of income, employment, prices and the balance of payments. Most economists who have examined the basis of monetary policy have approached it by postulating a behavioral link between these stabilization objectives and some indicator of monetary policy, such as free reserves, the money stock or the Treasury-bill rate. This approach to measuring monetary policy has several important drawbacks. ${ }^{2}$ For the reasons given in footnote 2 and in the Appendix, this study does not attempt to link stabilization objectives to ultimate target values of income, employment and prices. Instead, a proxy variable will be used as a summary measure of the stabilization policy objectives of the central bank.

The proxy used is free reserves. Movements in free reserves are highly correlated with changes in the policy directives of the Federal Open Market Committee (FOMC), which is the key monetary policymaking body of the Federal Reserve. The accompanying chart illustrates this close association between the level of free reserves and a quantification of FOMC directives. This quantification of the FOMC directives was constructed from a procedure developed by Professors Karl Brunner and Allan Meltzer. ${ }^{3}$ They examined the policy directives from March 1946 to December 1962 and assigned a value between +1 and -1 to each directive, according to whether it called for ease or tightness relative to current condi-

2First, the policy objectives may not be independent of one another. Attempts to achieve one target (eliminating infla tion) nay cause a movement away from another desired target (reducing unemployment), Because it miky be impossible to satisfy, simultaneously, two policy targets with one policy tool, the policymaker may choose to achieve one target one time and the other another time. Given the statistical tools at hand, it may not be possible for the economist to discriminate between these varying responses. Second, the preferences of the policymaker with respect to achieving desired levels of alternative target variables may be interdependent. For example, the disutility of the policymaker associated with missing a price stability target may not be independent of how far other stabilization targets are missed. Finally, there are serious statistical difficulties in constructing a systematic statement of the Federal Reserves response to discrepancies between observed and de. sired levels of target variables when the observed values of the target variables show little variation during a significant part of the period. These issues are discussed more fully in the Appendix.

"Karl Brumer and Allan Meltzer, "An Alternative Approach to the Monetary Mechanism," House of Representatives, Comrnittee on Barking and Currency, Subcommittee or Domestic Finance, U.S. Govermment Printing Office, August 17,1964 . The scale and thus the absolute values assigned to each directive is arbitrary. Only the sign is important. The same absolute values of the accumulated directives at different points in time are not necessarily comparable.

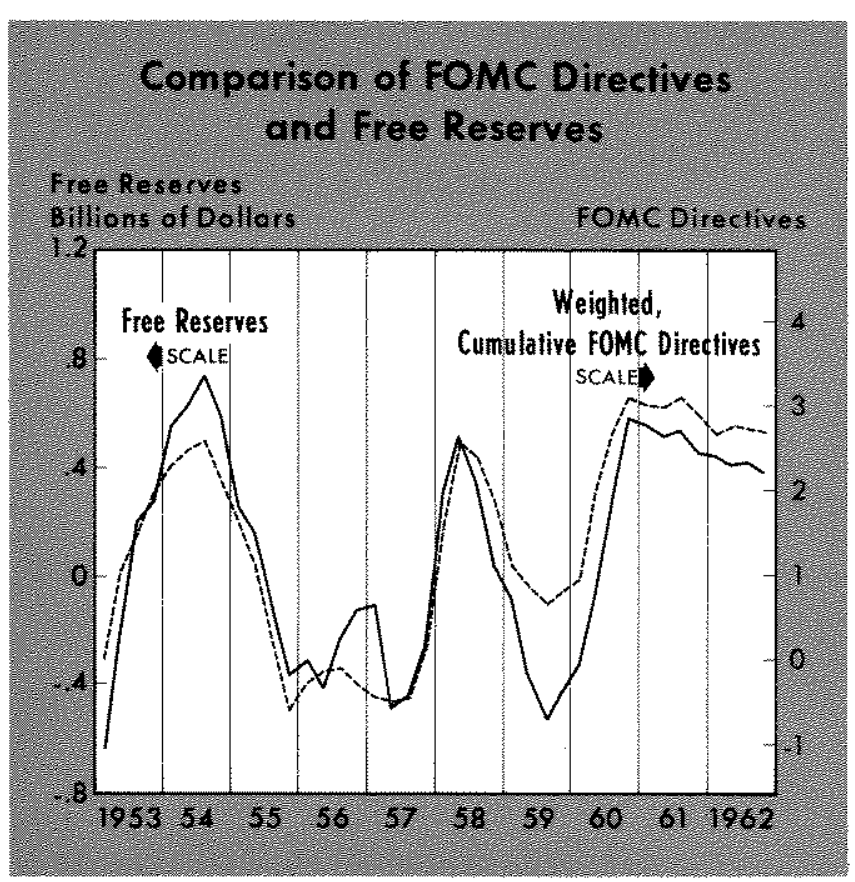

tions. If the Federal Reserve had been following a restrictive policy but did not wish to be any more restrictive, the FOMC directive would call for no change and the number assigned to that directive would be zero. A move toward restraint was assigned a negative value and a move toward ease, a positive value. To measure the progressive easing or tightening reflected in FOMC directives over time, the assigned values were accumulated. It is these accumulated values which are plotted in the accompanying chart. ${ }^{4}$

The quantified FOMC directives are plotted only from 1953 to 1962 , because directives prior to 1953 were largely concerned with stabilizing the market price of Covernment securities and thus were irrelevant to our present purpose of measuring stabilization objectives. Directives, after 1962, were not quan-

tThere are two interpretations which can be put on the accumulation procedure. First, it conld imply that when the directive called for tighter money market conditions than those previously prevailing, monetary policy is tighter. Second, it could imply that policy is not tighter, but that previous tightening in money market conditions had not achieved the desired objectives, and that greater tightening in money market conditions is necessary to achieve the desired tightening in policy, In the first case, desired policy is always realized, and therefore, the cumulative directive measures a change in desired policy. In the second case, desired policy differs from the observed index, and the progressive tightenitig in the directive represents an attempt to eliminate the discrepancy, so the accumulative directive is always moving in the right direction. Either interpretation of the directive is consistent with the accumulation procedure. The shorter the time period, the more likely that the second interpretation is correct, and the longer the time period, the more likely the first interpretation is correct. The use of quarterly observations in this study supports the first interpretation. 
tified by Karl Brunner and Allan Meltzer in their 1964 article. $^{5}$ Virtually every change in the FOMC directives after 1952 was related to an expressed concern for inflation, unemployment or the balance of pay ments. For this reason the directives are considered a good indicator of the stabilization objectives of the Federal Reserve. ${ }^{6}$ The patterns of movement in the free reserve and FOMC directive series are quite close. Every turning point in free reserves and even the magnitudes of most changes are fairly accurately reflected in the quantification of the directives. The correlation coefficient between free reserves and the accumulation of the Brunner-Meltzer quantification of the directive for the period 1953-62 is 0.87 . The authors used the Brunner-Meltzer procedure to quantify the directives in the period 1963 to 1968 , and the relationship with free reserves was unchanged (cor" relation coefficient of 0.86 ).

The use of free reserves as a proxy measure of stabilization objectives of the Federal Reserve has also been followed by other economists who have attempted to analyze Federal Reserve behavior. Most of these economists assumed that the full concern of the Federal Reserve was directed toward stabilizing the growth of income, employment, prices and attain ing equilibrium in the balance of payments. With only stabilization objectives in mind, their results led them to conclude that free reserves are "the most reliable indicator of monetary policy." Finally, the Federal Reserve itself seems to place strong reliance on free reserves as a measure of monetary policy:

"A downward trend in net free reserves over a period of several months preceding a particular action confirms that Federal Reserve policy has been tending to become somewhat less stimula-

5Meltzer has very recently extended the quantification through March 1969. However, it was not available in time to be used in this paper.

Even-keel is mentioned many times in the FOMC directives, but only as a reason for delaying a change in policy, never as a reason for taking action.

${ }^{7}$ See John Wood, A Model of Federal Reserve Behavior, Staff Economie Study No. 17, Board of Governors of the Federal Reserve System, p. 14. William G. Dewald and Harry G. Johnson, "An Objective Analysis of the Objectives of American Monetary Policy, 1952-61," Banking and Monetary Studies, ed. Deane Carson (Homewood, Illinois: Richard D. Irwin, 1963), and James W. Christian, "A Further Analysis of the Obfectives of American Monetary Pol. icy," The Joumal of Finance, volume XXIII, June 1968, have found that the movement in free reserves can be explained as a response aimed at achieving stabilized values for income, employment, prices and the balance of payments. Separately, Dewald "Free Reserves, Total Reserves and Monetary Control," Joutnal of Political Economy. April 1963, indicates that the monetary policy can be closely approximated by the movement in free reserves. tive with regard to the growth of credit and money than it had been earlier. . . In general, the net reserve position of member banks is an important gauge of pressure on bank reserves. When net free reserves rise, the result is increased marginal availability of reserves which the banking system can readily use to expand credit . . .8"

Free reserves are used in this article only as a proxy for the stabilization objectives of the FOMC. Their use should not be taken to imply that we consider free reserves to have any causal impact on bank behavior. The evidence marshaled against free reserves as an important causal link in the monetary process is impressive." In this article we assume that the ultimate stabilization goals with respect to income, employment, prices and the balance of payments, when filtered through the preference function of the FOMC, are approximated by the level of free reserves.

\section{Measuring Other Federal Reserve Objectives}

An assumption of this paper is that stabilization of income, employment and prices is an important, but not the only objective of the Federal Reserve. Two other objectives embedded in the Federal Reserve history and practices are: (I) assisting the United States Treasury Department "to make a market" during periods of debt financing, a practice which is generally referred to as "even-keel"; and (2) performing the role of bank of last resort by protecting financial institutions and financial markets from collapse or serious "disorderly conditions."

The even-keel objective may be a carryover of the Federal Reserve's single-minded policy during and just after World War II of pegging the market price of Government securities. This policy was pursued with the expectation that unless the capital value of the public's and banks recently increased holdings of Government debt was maintained at, or close to, its face value, a large share of it would be redeemed or sold in the open market, making debt management difficult. Until this policy was officially abandoned after the March 1951 Accord with the Treasury, Federal Reserve actions were strictly subordinated to the needs of debt management. The Accord was designed

SThe Federal Reserve System: Purposes and Functions, 5th Edition, Board of Governors of the Federal Reserve System, Washington, D.C., 1963, pp. 222-23.

9 See A. James Meigs, Free Reserves and the Money Supply (Chicago: University of Chicago Press, 1962). 
to allow the Federal Reserve to pursue stabilization objectives with respect to income, employment and prices - objectives which became increasingly important with the intensification of the Korean War.

The even-keel objective is designed to stablize Government security prices during the period when the Treasury is in the market. An even-keel period can last for as long as several weeks for each issue of securities. It is believed that private dealers, who are the initial purchasers, need to be assured that they will not face the risk of a capital loss in order to induce them to "make a market" in Government securities. ${ }^{10}$ Because these dealers borrow short-term funds to finance their inventories of Government securities, even-keel amounts to providing a "neutral" short-term money market during the period of Treasury financing.

The second nonstabilization objective of the Federal Reserve is related to its role as the bank of last resort and guardian of the U.S. financial system. The financial panic of 1907 was the cause celebre that eventually led to establishment of the Federal Reserve System in 1914. The Federal Reserve's concern with the viability of the financial system is not simply due to a desire to protect this one segment of the economy. The history of depressions in the United States has shown that the deepest and most severe have been associated with financial panics. A major criticism of the Federal Reserve's behavior in the early Thirties is that the major depression of that period was exacerbated by the financial collapse, which some argue the Federal Reserve could have prevented.

According to some authorities, the Federal Reserve's objective of maintaining the viability and solvency of financial institutions and markets is more difficult to achieve during periods of extended prosperity when interest rates are rising. There are several sources of financial instability: general financial panic, special problems for savings and loan associations (S\&L's), and the housing industry. Hyman Minsky has discussed the conditions which could lead to a general financial collapse. ${ }^{11}$ His model implies a behavior pattern of the following sort. Prosperity and economic boom conditions interact with expectations in a way which makes it likely that with rising in-

\footnotetext{
10In addition, the Federal Reserve has taken the position that Government security dealers, during a Treasury financing, should not receive a capital gain as a result of the Federal Reserve's role in the market.

11.Hyman Minsky's position is presented in "Can 'It" Happen Again," Banking and Monetary Studies, ed. Deane Carson (Richard D. Irwin, 1963).
}

terest rates, private persons and institutions assume liquidity-debt ratios which are relatively narrow and therefore vulnerable to a slowdown in the growth of either income or the money stock. According to Minsky, the Federal Reserve should be cautious of ag. gressively engaging in restrictive monetary actions during periods of extended prosperity, because "disorderly" markets may develop and possibly snowball into a full-scale financial panic such as occurred in the early Thirties.

Conversely, during periods of extended economic slowdown, private persons and institutions assume liquidity-debt ratios which are relatively large and, therefore, a potential source of future inflation. During such periods, the Federal Reserve may be cautious of aggressive easy monetary actions because it would add to inflated liquidity positions and consequently frustrate monetary control in the future. ${ }^{12}$

However, the Federal Reserve is not only concerned with the possibility of overall financial instability. It has two additional financial concerns related to interest rates which are narrower in their focus. First, for certain financial institutions, high and rising interest rates by themselves can bring about financial instability. In particular, by borrowing short and lending long, the S\&L's have created portfolios which have left them vulnerable to upward secular shifts in interest rate levels. During periods of rapidly rising interest rates, S\&L's become "locked-in" to their long-term, relatively low interest rate assets, which means that their net worth will decline and their profit margins will be depressed. Another objective related to interest rates is the Federal Reserve's desire to lower rates to encourage the growth of interest-rate-sensitive sectors of the economy, such as housing construction.

In the spirit of quantitative analysis in which this article is written, we attempt to measure the evenkeel and financial system objectives of the Federal Reserve. Because there is no generally accepted meas. ure of even-keeling, or of the Federal Reserve's role as the bank of last resort, a certain amount of experimentation was conducted. Even-keel is mentioned in the FOMC directives whenever the Treasury is

\footnotetext{
12Federal Reserve Annual Report, 1937, p. 2. In referring to the increase in reserve requirements in March and May 1937 , the reason given "... was in the nature of a precautionary measure to prevent an uncontrollable expansion of credit in the future." At that time the Aaa corporate bond yield was 3.3 per cent; the consumer price index was 16 per cent lower than in 1929 , and the unemployment rate was 14 per cent.
} 
refinancing old debt or financing new debt. However, a new debt issue is presumed to require greater Federal Reserve action than refinancing old debt. In the former case, the net increase in supply of securities to the market would be equal to the size of the new debt issue; in the latter case, there would be no net increase in the supply of sccurities because the Treasury would have paid off the holders of old Government securities. Thus, most important Federal Reserve actions are assumed to be associated with the issue of new debt. This is measured by changes in the national debt held outside of the trust accounts of the Federal Government $(\Delta D) .^{13}$

We have selected, as our proxy of the Federal Reserve's concern for the viability of financial institutions, the deviations of the corporate Aaa bond yield from its "normal" level. ${ }^{14}$ Interest rates which are higher than "normal" are taken as a signal to the Federal Reserve that financial institutions are more vulnerable to restrictive monetary actions by the Federal Reserve. In addition, higher than normal rates have an adverse effect on S\&L's and the housing construction industry, which the Federal Reserve finds undesirable. On the other hand, lower interest rates would be indicative of high liquidity-debt ratios, implying a concern on the part of the Federal Reserve that highly liquid, that is, sloppy financial markets would make control of future inflation difficult. ${ }^{15}$ The behavior of the Federal Reserve under these circumstances would be to act in a way to increase the supply of funds when the interest rate was above normal and to act in a way to decrease the supply of funds when the interest rate was below normal.

\footnotetext{
13There may be some justification for including debt held in the Government's trust funds in the total because the Treasury manipulates purchases and sales by the trust funds according to the needs of smooth debt management.

${ }^{14}$ In the context of this article, the normal interest rate is one at which the financial system is in long-run equilibrium. Theoretically, that would equal the real rate of return on risk-free investment plus an adjustment for price expectations. Most studies indicate that when prices are changing relatively slowly (as in the United States), price expectations are adjusted after a $15-20$ year lag.

15This concern about future inflation should not be confused with stabilization objectives. Stabilization objectives represent a concern with present levels of income and employment. The financial objective in this case represents a concern that the highly liquid state of financial institutions would make future anti-inflationary actions less effective. The Federal Reserve did not expect that its raising reserve requirements in 1937 would do anything more than "sop up" the unneeded excess reserves of member banks. The fact that it led to a sharp recession in 1938 was an unintended and undesired consequence.
}

\section{Measuring Federal Reserve Actions}

The criteria used for selecting a particular monetary aggregate as the measure of Federal Reserve actions are: (1) that its value be dominated by the actions of the Federal Reserve, and (2) that it have an important and measurable effect on total demand.

With respect to the first criterion, the Federal Reserve has three traditional tools which it can control completely: open market operations, changes in reserve requirements, and the discount rate. ${ }^{10}$ Open market operations are measured by changes in Federal Reserve holdings of Government securities, changes in reserve requirements by changes in the dollar amount of required reserves (holding the dollar value of deposits and their distribution by class of bank constant), and the discount rate by the amount of borrowing of member banks. It is widely acknowledged that open market operations and changes in reserve requirements are the primary monetary tools, and that the discount rate is at best only of secondary influence.

One way to combine the two primary tools into one quantifiable measure of Federal Reserve actions is by adding a "reserve adjustment" to changes in Federal Reserve holdings of Government securities. ${ }^{17}$ This series (adjusted Federal Reserve holdings of Government securities) meets the first criterion, because the value can change only if the Federal Reserve takes some action on the open market or changes reserve requirements. However, this series does not satisfy the second criterion, that of having an important and measurable influence on total demand. Previous research published in this Review and elsewhere has presented theoretical justification and empirical evidence which indicate that the monetary base has an important influence on total spending. The dominant source component of the monetary base is Federal Reserve holdings of Government securities adjusted for changes in reserve requirements. ${ }^{18}$ This can be seen in Table 1 , which lists all sources of the monetary base.

${ }^{16}$ The Federal Reserve also has an array of regulations, A through $\mathrm{Z}$, which are designed to influence conditions in certain specified markets. It is our position that however substantial the impact of these regulations on the affected markets, their impact on the total economy is small; thus, they are not considered in this article.

${ }^{17}$ See Leonall C. Andersen and Jerry L. Jordan, "The Monetary Base - Explanation and Analytical Use," in the August 1968 issue of this Review.

1*Without the reserve adjustment, Federal Reserve holdings of Government securities is a component of the source base. The difference between the source base and the monetary base is this same reserve adjustment. 


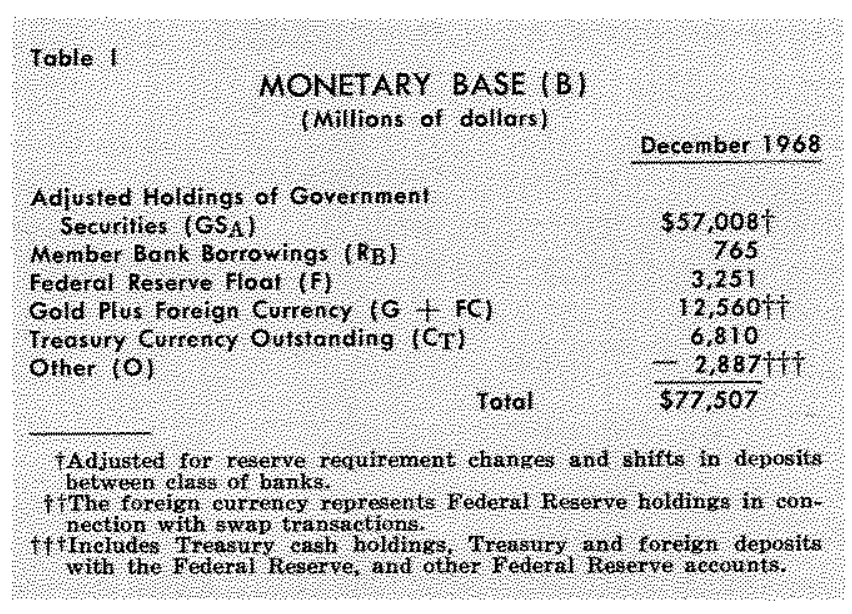

The monetary base ( $\mathrm{B}$ ) can be defined as:

$$
\mathrm{B}=\mathrm{GS}_{\mathrm{A}}+\mathrm{RB}_{\mathrm{B}}+\mathrm{F}+(\mathrm{G}+\mathrm{FC})+\mathrm{CT}+\mathrm{O}
$$

where Federal Reserve holdings of Government securities (adjusted) are under direct control, and other components, such as float, gold and foreign currency holdings, and Treasury currency, are not under direct control of the Federal Reserve. Float depends upon the amount of check transactions and therefore on the level of business activity; gold and foreign currency holdings are related to the U.S. balance of payments and intemational monetary conditions.

The sources of the monetary base which are outside direct control of the Federal Reserve could have an important impact on domestic money market conditions because of their effect on the reserve positions of member banks. Consequently, if the Federal Reserve wishes to prevent these flows from influencing money markets, it must take defensive actions by changing its holdings of Government securities. Thus, in addition to the primary goals of economic stabilization, even-keel and financial objectives of the Federal Reserve have a narrow technical objective of avoiding disturbances to the money markets caused by movements in these noncontrollable sources of the base.

To analyze how much Federal Reserve actions are directed toward offsetting the influences of these noncontrollable sources of the monetary base on money markets, a regression of the following first difference form was tested:

$$
\begin{gathered}
\Delta \mathrm{GS}_{\mathrm{A}}=\mathrm{a}_{0}+\mathrm{a}_{1} \Delta \mathrm{RB}_{\mathrm{B}}+\mathrm{a}_{2} \Delta \mathrm{F}+\mathrm{a}_{3} \Delta(\mathrm{G}+\mathrm{FC}) \\
+\mathrm{a}_{4} \Delta \mathrm{CT}+\mathrm{a}_{5} \Delta \mathrm{O}
\end{gathered}
$$

Changes in adjusted holdings of Government securities is on the left-hand side, and changes in the other sources of the monetary base, which the Federal Reserve does not directly control, are on the right-hand side. If the Federal Reserve acts to prevent all or part of the movements in these uncontrolled sources of the base from influencing money markets, it would show up in the form of statistically significant coefficients between $\left(G S_{A}\right)$ and each of the variables on the right-hand side. Using monthly data from January 1953 to December 1968 , the following results were obtained (numbers in parentheses are $t$ values): ${ }^{19}$

$$
\begin{aligned}
\Delta \mathrm{GSA} & =.132-.81 \Delta \mathrm{RB}-.49 \Delta \mathrm{F}-1.02 \Delta(\mathrm{G}+\mathrm{FC}) \\
& +.50 \Delta \mathrm{CT}+.9 \mathrm{~T} \Delta \mathrm{O}(11.01) \\
& (.91)(7.68)
\end{aligned}
$$

Except for Treasury currency, all of the coefficients are statistically significant at the 5 per cent level, which means the probability that there is no "real" relation between the dependent and independent variables is less than one in twenty.

Not only does the Federal Reserve respond to these other components of the monetary base, but its response is such as to offset their influence on the monetary base. That is, if the amount of float, member bank borrowings, or gold inflow should increase, this would, ceteris paribus, add to the monetary base as can be seen in Table 1. Because the coefficients of each of these variables are negative ${ }^{20}$ and close to one in absolute value, it is possible to deduce that adjusted Federal Reserve holdings of Government securities has been manipulated in a way that the monetary base will not change significantly. In the process of achieving its short-term money market objectives, the Federal Reserve has tended, in effect, to offset uncontrolled movements in the monetary base.

Under these circumstances, Federal Reserve actions can be measured either as changes in adjusted holdings of Government securities, with this measure related to three primary objectives and one technical money market objective, or as changes in the monetary base related to just the three primary objectives. Because it has been demonstrated that the monetary base has an important impact on total demand, it is desirable to use this variable. In addition, it is necessary to use the monetary base if we wish to analyze

1:The variables in all regressions are seasonally adjusted unless otherwise specified.

$20 \Delta O$ has an expected sign and magnitude of +1 because it refers to changes in other Federal Reserve accounts. These other accounts consist largely of Treasury and foreign deposits which are liabilities of the Federal Reserve, and, as such, are entered as negative values of the source base as illustrated in the above table. In this case, an increase in this variable wotld decrease the monetary base, and therefore the appropriate offset would be an increase in Federal Reserve holdings of Government securities. 
the actions of the monetary authorities in the prewar period when the Treasury department exercised a dominant role in monetary actions.

For the postwar period, equally satisfactory and consistent results are obtained using either $\Delta \mathrm{B}$ or $\triangle \mathrm{GS}$ A to measure Federal Reserve actions. A choice between these two variables depends upon whether or not one desires to give explicit consideration to technical money market objectives. If these objectives are important, then $\Delta \mathrm{GS}_{\mathrm{A}}$ is appropriate. If not, $\Delta \mathrm{B}$ is appropriate.

\section{Federal Reserve Actions - The Explanation}

The beginning of this article referred to the alleged discrepancy between monetary policy and Federal Reserve actions. We have defined monetary policy as reflected in the directives of the FOMC and proxied by the level of free reserves. In addition, Federal Reserve actions other than those related to short-term money market considerations can be measured by changes in the monetary base. It is clear from even casual inspection of the chart on page 17 that the two series are not closely related. There is a pronounced cyclical pattern in both series, which moved together in 1958-59 and 1966-67, but not in 1953, 1955, 1963-64 and 1968. The absence of a systematic relation between the two series is confirmed by the following regression, which relates the Federal Re- serve action variable $\Delta \mathrm{B}$ and the monetary policy or economic stabilization variable $\mathrm{FR}$.

$$
\Delta \mathrm{B}=.428+\underset{(.86)}{0.11(\mathrm{FR})} \quad \mathrm{R}^{2}=.012
$$

The value of the coefficient $(0.11)$ is not statistically significant, and explains only 1 per cent of the variation in Federal Reserve actions $(\Delta B)$. We will explain this discrepancy between stated monetary policy and Federal Reserve action by its desire to achieve even-keel and financial objectives.

There are undoubtedly other influences on Federal Reserve actions, such as changes, in the personnel of the Federal Reserve's decisionmaking apparatus, and changes in Presidential Administration. In spite of these obvious limitations, we believe our attempts to explain Federal Reserve behavior are reasonably satisfactory.

The accompanying table shows the regression relationships between our measure of Federal Reserve actions $(\Delta B)$ and proxies of the stabilization, evenkeel and financial objectives which this paper asserts the Federal Reserve has desired to achieve. There are two panels of results, one for quarterly central differences and one for quarterly first differences. In each panel, the first column presents the results for the period since the Korean War, 1953 to 1968 . The second column shows the results for the war and

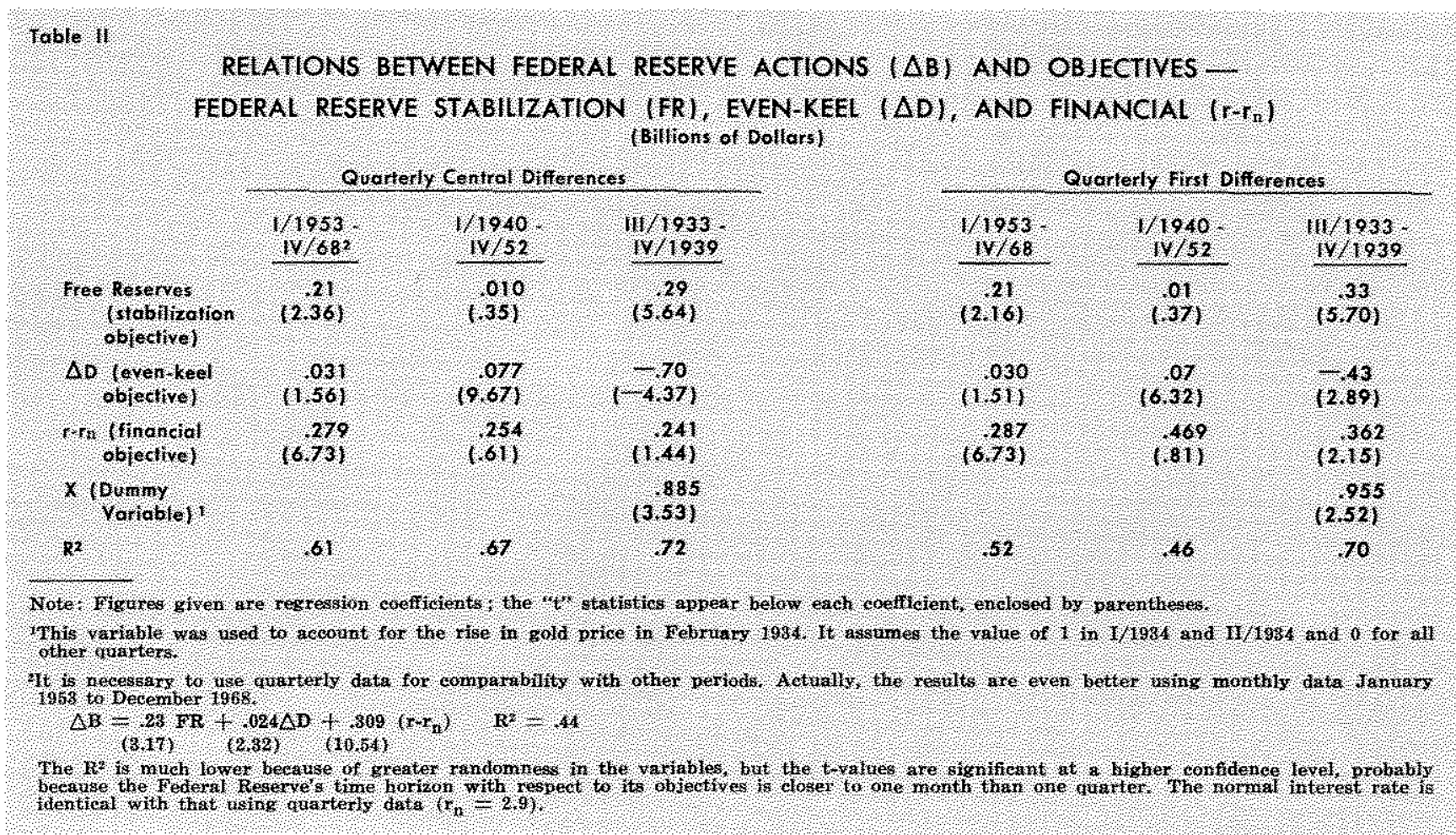


early postwar years, 1940 to 1952 . The third column shows the results for the period 1933 to 1939. Each of these results will be analyzed in turn.

\section{Mature Postwar Period - I/1953 to IV/1968}

A substantial proportion of the variations in Federal Reserve behavior $(\Delta B)$ is explained by our proxies of Federal Reserve stabilization, financial and even-keel objectives. The signs of all the coefficients are positive, which is as would be expected. An increase in FR would indicate an easy money policy and therefore an increase in $\Delta B$. An increase in the national debt would require additional even-keel actions of the Federal Reserve and therefore an increase in $\Delta B$. An increase in interest rates would cause an increase in the Federal Reserve's concern for the stability of the financial system and therefore an increase in $\Delta \mathrm{B} \cdot{ }^{21}$

To evaluate properly the policy implications of these results, we must determine which of the explanatory variables has made the largest contribution to changes in the monetary base $(\Delta \mathrm{B})$. Such an evaluation cannot be done by simply comparing the values of the regression coefficients, because the explanatory variables are all in different dimensions. However, the regression coefficients can be standardized by computing beta coefficients. ${ }^{22}$ The beta coefficients for the 1953-68 period are 0.21 for the stabilization objectives, 0.16 for the even-keel objectives and 0.68 for the financial objective. These results suggest that in the postwar period Federal Reserve behavior was dominated by the consideration of pro-

21The normal interest rate in the financial objective, $\mathbf{r}_{\mathfrak{n}}$, is the product of a ratio computed from the coefficient with respect to $r$ and the value of the constant term. This procedure simultaneously suppresses an unrealistic negative constant term and eliminates the implication that any positive value for $r$ will lead to an increase in the monetary base. Using this procedure, the normal interest rate is 2.8 per cent for 1953-68, 2.9 per cent for 1933-39 and 2.4 per cent for $1940-52$. Considering the method of calculation, the values are quite close.

A variety of other techniques were tried to determine the value of $\mathrm{r}-\mathrm{r}_{\mathrm{n}}$. Various arbitrary values of $\mathrm{r}_{\mathrm{n}}$ were selected and deviations were computed of a cubic, quadratic and linear form. The results of these experiments are similar to the results reported here.

22:"Beta coefficients" are used to determine the "typical impact" or importance of the explanatory variables in a regression. It should be noted that treta coefficients are equivalent to the regression coefficients of a regression run on "standardized" variables of the form $X_{j} / S_{j i}$ where $X_{j}$ is the variable, and $S_{j j}$ is its standard deviation. An analysis based on beta coefficients, instead of regression coefficients, eliminates the necessity of assessing the impact that the units of measurement have on the relative sizes of the coefficients in a regression, and this reduces the possibility of a faulty interpretation of the regression results. See Arthur S. Goldberger, Econometric Theory (John Wiley \& Sons, 1964), pp. 197-98. tecting the financial system, while stabilization policy and even-keel objectives were of secondary and about equal importance. ${ }^{23}$ If we attempt to scale Federal Reserve behavior with respect to these explanatory variables, about one-fifth can be explained by stabilization objectives, while the remainder can be explained in terms of achieving even-keel and financial objectives.

Similar results are achieved when Federal Reserve actions are measured by changes in adjusted Federal Reserve holdings of Government securities $\left(\Delta G S_{A}\right)$ when the short-term money market objective is included. Using monthly central difference data from January 1953 to December 1968 , the results are as follows: ${ }^{24}$

$$
\begin{aligned}
& \Delta \mathrm{CS}_{\mathrm{A}}=+.207(\mathrm{FR})+.03 \Delta \mathrm{D}+.309\left(\mathrm{r}-\mathrm{r}_{\mathrm{n}}\right)-.93 \Delta \mathrm{RB} \\
& \begin{array}{llll}
(2.38) & (2.39) & (8.39) & (7.16)
\end{array} \\
& -.59 \Delta \mathrm{F}-.85 \Delta(\mathrm{G}+\mathrm{FC})-.74 \Delta \mathrm{CT}+.90 \Delta \mathrm{O} \\
& \begin{array}{lll}
(3.62) & (10.89) \quad(1.56) \quad \text { (9.11) }
\end{array} \\
& \mathrm{R}^{2}=.69
\end{aligned}
$$

The coefficients are almost identical with respect to stabilization, even-keel and financial objectives, as in the case of using the monetary base $(\Delta B)$ as the dependent variable. With respect to the short-term money market objective, the results are about the same as those presented on page 12 . The monetary base and adjusted Federal Reserve holdings of Government securities are equally consistent measures of Federal Reserve actions. As stated earlier, the choice between them depends upon whether one wishes to explain these actions with or without reference to short-term money market objectives.

\section{War and Early Postwar Period- I/1940 to $\mathrm{WV} / 1952$}

During World War II and the early postwar period it has been generally considered that Federal Reserve actions were dominated by the desire to support the U.S. Treasury in financing the large and rising national debt. Our results clearly indicate that financing the national debt played the dominant role in Federal Reserve behavior during this period. The debt variable is highly significant statistically, while

\footnotetext{
23 When the coefficients were estimated for the period 1953-65 their values were about the same as those reported for the period 1953-68. However the beta coefficient for interest rates was lower and about equal to the product of the other two. This is as would be expected because the financial objective has been of increased importance in the 1966-68 period.

$2 \mathrm{FF}$ and $\mathrm{r}-\mathrm{r}_{\mathrm{n}}$ are variables measured at monthly levels, so the estimated monthly coefficients were multiplied by three to make them conparable with the coefficients estimated with quarterly data.
} 
the other variables are not. The beta coefficients for stabilization and financial objectives are insignificant, and for $\Delta \mathrm{D}$ are 809 . The debt variable dominated $\Delta \mathrm{B}$ in the war and early postwar period.

\section{Prewar Period - LI/1933 to IV/1939}

The Federal Reserve went through a chaotic and trying experience during the 1929-33 period because of the Great Depression, the international monetary collapse and the domestic financial panic. The Federal Reserve apparently withdrew from active monetary management during the period 1933-39. This lack of action can be seen from the fact that Federal Reserve credit changed very little from early 1933 to the end of 1939 and varied on the average by less than $\$ 47$ million per quarter, compared with $\$ 635$ million per quarter in 1953-68..$^{25}$

In effect, the Treasury Department carried on active monetary management during this period by the rate at which it permitted the monetization of the large gold inflows. It is interesting to note that in spite of the different economic conditions and the Treasury's performing the active role of monetary management during much of the period, the behavior of the monetary authority was similar to its behavior in the 1953.68 period relative to the same set of explanatory factors. The stabilization (FR) and financial system $\left(r-r_{n}\right)$ objectives are significant, and their coefficients have about the same value in both periods. The even-keel variable $(\Delta D)$ is statistically significant; however, the sign of its coefficient is opposite that of the sign for the mature postwar period. ${ }^{26}$ For

${ }^{2}$ See various issues of the Federal Reserve Bulletin.

260 The different signs of the coefficient of the even-keel variable $(\Delta \mathrm{D})$ in the prewar and mature postwar periods can be explained by two factors:

(1) In the prewar period even-keel needs were insignificant, while in the mature postwar period they were large.

(2) The Treasury was the major monetary authority in the prewar period, while the Federal Reserve performed that role in the mature postwar period.

Even-keel considerations were not important in financing the growing Government debt in the middle and late Thirties because short-term: money markets were on average very liquid, and the demand for default-free Government securities by a strongly risk-averting public was great. In the mature postwar period, short-term noney markets were on the average much less liquid, and the public's demand for Covernment securities as a protection against the risk of defanlt of private securities was small. This explains why the even-keel variable ( $\Delta D$ ) was positive in the mature postwar period and nonpositive in the prewar period.

The even-keel variable $(\Delta D)$ was negative in the prewar period because the Treasury Department was in active control of monetary management. This control of the monetary base was achieved by regulating the rate at which the preasury monetized the heavy gold intlows of the middle and late Thirties. The Treasury reduced the growth in the monetary base by financing the gold inflow out of reasons explained in footnote 26 , this is largely due to the Treasury Department assuming active monetary management in this period. The beta coefficients for this period were 0.85 for stabilization, 0.25 for financial and -0.62 for even-keel objectives. Considering the magnitude of the decline in employment, prices and income, which occurred in the early Thirm ties, it is not surprising that the beta coefficients imply that the major factors determining monetary authority behavior in the middle and late Thirties were stabilization objectives related to increasing income and employment. An important factor explaining the relatively low beta coefficient for the financial objective was that $r-r_{11}$ did not change much during this period. The large size of its coefficient implies that, if it had varied significantly, it would have played a more significant role in determining Federal Reserve actions.

\section{A Statistical Digression}

An examination of the differences between the value of $\triangle B$ estimated by the equation and the actual value of $\triangle B$ for the period 1953 to 1968 indicates the presence of what, in statistics, is called serial correlation in the residuals. The usual interpretation is that some important explanatory variable has been omitted. As indicated before, a potentially serious deficiency in our explanation of Federal Reserve behavior is not taking account of the changes in Presidential Administration. Although the laws establishing the Federal Reserve and the practices which have developed over the years provide it with more autonomy than is enjoyed by most central banks, it is not completely insensitive to the desires and wishes of the President and his immediate advisers. Thus, it is possible that Federal Reserve's behavior may differ between Presidential Administrations. This possibility was tested very crudely by introducing a "dummy" variable, $\mathrm{X}_{1}$, to see if Federal Reserve actions other than for previously stated objectives differed between the two administrations. ${ }^{27}$ The re-

general Government funds, thereby increasing the national debt by more than would otherwise have been the case. The Treasury increased the growth in the monetary base by nonetizing current gold inflows plus accumulated Treasury gold stock through sales of gold certificates to the Federal Reserve, thereby reducing the size of the national debt from what it otherwise would have been.

${ }^{27}$ The dummy variable assumes the value of zero for $I / 1953$ to II/1962 and the value of one from III/1962 to IV/1968. The third gtuatter of 1962 was selected for two reasons. First, this was the first quarter when the Federal Government budget was under the complete control of the incoming Democratic Administration. Second, the link between the Presidential Administration and the Federal Reserve is informal and adaptive, and it is reasonable to assume that a change in Federal Reserve behavior would occur gradually. 
sults of the test using quarterly central difference data (billions of dollars) and the monetary base $(\triangle B)$ from 1953 to 1968 are as follows:

$$
\begin{aligned}
& \Delta \mathrm{B}=.18(\mathbf{F R})+.03 \Delta \mathrm{D}+.112\left(\mathrm{r}-\mathrm{r}_{\mathrm{n}}\right)+.428 \mathrm{X}_{1} \\
& \text { (2.92) } \quad(2.00) \quad(3.11) \quad(7.85) \\
& \mathrm{R}^{2}=.81
\end{aligned}
$$

The results using adjusted Federal Reserve holdings of Government securities monthly for the same period are as follows:

$$
\begin{aligned}
& \Delta \mathrm{CSA}_{\mathrm{A}}=.159(\mathrm{RR})+.04 \Delta \mathrm{D}+.117\left(\mathrm{r}-\mathrm{r}_{\mathrm{Fx}}\right)+.155 \mathrm{X}_{1} \\
& \begin{array}{llll}
(2.01) \quad(3.25) \quad(2.67) & \text { (6.71) }
\end{array} \\
& -1.02 \Delta \mathrm{FB}_{\mathrm{B}}-.50 \Delta \mathrm{F}-.89 \Delta(\mathrm{G}+\mathrm{FC}) \\
& \text { (8.69) (3.41) (12.70) } \\
& -.70 \Delta \mathrm{CT}+.85 \Delta \mathrm{O} \\
& \text { (1.65) } \quad(9.56) \\
& \mathrm{R}^{2}=.75
\end{aligned}
$$

The fact that the coefficient of the dummy variable, using monthly data, is only one-third of the coefficient when quarterly data was used (.155 versus .428 ) is due to the difference in time dimension (monthly data compared to quarterly data). The results of these tests are very similar. In both cases a larger percentage of Federal Reserve actions is explained by explicitly accounting for the change in administrations, and serial correlation in the residuals is substantially reduced. The values of the coefficients of the other variables were not changed significantly except for $r-r_{n}$, which has a lower value. The dummy variable undoubtedly overstates the difference between the two administrations because it seems to capture some of the influence of the interest rate variable.

\section{Summary of Results}

Before summarizing our results, it is important to note that Federal Reserve behavior in the period 1929-33 has been characterized by most students as "inappropriate." The monetary policy objective of stabilizing income and employment was pursued in a most timid manner and was easily displaced by international monetary concern. ${ }^{28}$ For example, when the United Kingdom went off the gold standard in September 1931, the Federal Reserve temporarily switched to a highly restrictive policy, even though it was widely recognized that the United States was in the midst of a serious depression. As that depression deepened, some banks failed because the Federal Reserve did not perform the fundamental central banking task of acting as the "bank of last resort." This weakened public confidence in the financial

28 Milton Friedman and Anna Jacobson Schwartz, A Monetary History of the United States, 1867-1960 (Princeton: Princeton University Press, 1963), chapter 7. This is the most detailed and complete history of the monetary events in the $1929-33$ period. system, triggering a run on many banks. The massive number of bank failures which ensued, deepened and intensified the clepression of income and employment.

In contrast with the early Thirties, the restlts presented in this paper indicate that the monetary authorities have since behaved in a more consistent manner. Three objectives have determined their behavior: a stabilization objective with respect to income, employment and prices; a financial objective with respect to protecting the financial system from the recurrence of the events of the early Thirties, and the objective of supporting the Treasury Department in its debt-financing role, otherwise known as "even-keel." This consistency of behavior is observed irrespective of whether the Treasury (1933-39) or the Federal Reserve (1953-68) is performing the monetary management role.

During the middle and late Thirties when employment and income were at historic lows relative to the previous business cycle peak, our results indicate that stabilization objectives related to increasing employment and income dominated the behavior of the monetary authority. ${ }^{29}$ The monetary authority's behavior related to protecting the stability of the finan cial system can be detected during this period, but it was of secondary importance because those financial institutions which had survived the "events" of the early Thirties were highly liquid. The even-keel objective was insignificant in this period because the public, at that time, needed little encouragement to purchase default-free Government securities.

During the Fifties and Sixties employment was relatively high and income was growing at a generally satisfactory rate. Our results indicate that during this mature postwar period Federal Reserve actions were dominated by a desire to insure the stability of the financial system, especially in later years. This, of course, does not mean that income stabilization objectives never influenced Federal Reserve actions in the postwar period. On a number of occasions, such as in 1959 and 1966, stabilization objectives dominated Federal Reserve actions. However, when there was a conffict between objectives, the financial invariably dominated.

\footnotetext{
2t) There was one relatively short period in the first half of 1937 when monetary policy related to stabilization objectives became restrictive. This was the only period in the middle and late Thirties when monetary authorities' con" cern for the stability of the financial system overrode their concern for increasing employnent and income. See page 11, footnote 15 for further discussion of this issue.
} 


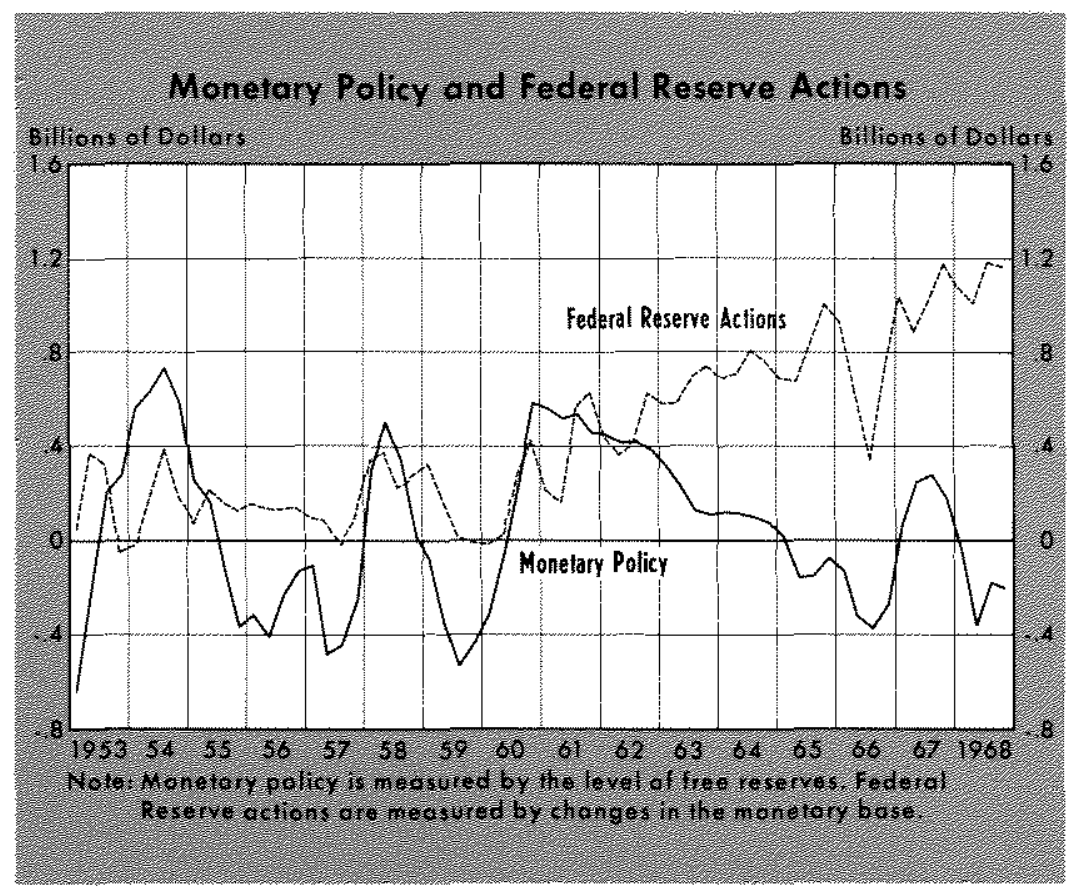

A clear example of this fact can be found by contrasting Federal Reserve behavior in 1966 and 1968. In the first half of both years, monetary policy, related to economic stabilization, was equally "tight." However, Federal Reserve actions, measured by changes in the monetary base, were tight in 1966, while they were not tight in 1968 . (Contrast free reserves and the monetary base in the above chart.) The difference between these two experiences was that the Federal Reserve was far more sensitive to consequences of its actions on financial markets in 1968 than it was in 1966. After the "credit crunch" of 1966, a great deal had been written about the "disorderly" financial markets and the threat this had posed to the stability of the financial system. Another factor contributing to the relatively easy monetary actions in 1968 was the large growth in the national debt, which had required that the even-keel objective be implemented frequently. This was not half so important in 1966 because of the smaller Government deficit.

\section{Conclusions}

The intent of this article is to show that Federal Reserve actions are not solely dictated by economic stabilization objectives. The Federal Reserve has independent even-keel and financial objectives which have, at times in the past, interfered with economic stabilization. This article by no means provides a definitive explanation of Federal Reserve actions. There may be other objectives which the Federal Reserve attempts to achieve, or there may be better ways of measuring the even-keel and financial objectives than the ones we have chosen. With this caveat, certain conclusions can be offered.

The behavior of the monetary authority with respect to stabilization and other objectives has been consistent. Our results imply that the monetary authority does in fact make some value judgments which discriminate between important objectives and less important objectives. The monetary authority cannot be criticized for behaving in an inconsistent manner.

A criticism which might be directed at the Federal Reserve is that some of the objectives they have chosen, or their relative weights have not been appropriate. The question as to whether or not the Federal Reserve has acted in an appropriate manner is not attempted in this paper. The answer to such a question would require more knowledge about the structure of the economy than is presented here. In general, the answer would depend on whether or not Federal Reserve actions have their dominant influence directly on income, employment and prices. If they do, the monetary behavior should be directed exclusively toward achieving desired levels of these variables because of their overwhelming impact on the welfare of our citizens.

If, on the other hand, monetary actions have their dominant influence on the financial system and perhaps on interest-rate-sensitive segments of the economy, such as the housing industry, it would be more appropriate for financial objectives to dominate the behavior of the monetary authorities. Because monetary actions would have relatively little direct influence on income, employment and prices in such a case, the monetary authority could only influence them indirectly by achieving its financial objectives. ${ }^{30}$

A considerable amount of evidence has developed in recent years which indicates that the behavior of the monetary authority has a substantial direct influence on income, employment and prices, which operates with a relatively short lag. Under such conditions, the appropriate behavior of the Federal Reserve in the 1953-68 period should have been to stabilize income, employment and prices, while, in fact,

\footnotetext{
nooutside of major war and national mobilization, there is no reasonable set of circumstances in which Federal Reserve actions should be dominated by even-keel objectives.
} 
their behavior was dominated by a desire to prevent short-run instability in the financial system.

Behavior dominated by financial objectives is potentially destabilizing. Federal Reserve actions designed to protect the financial system in a period of high and rising interest rates result in a more rapid growth in the monetary base than would otherwise be the case. This, in turn, leads to a rapid growth in income, employment (until the full employment constraint is reached) and prices. The inflationary price rises

This article is available as Reprint No. 42 . lead to an increase in interest rates and to greater strain on the financial system, inducing a further growth in the monetary base.

If Federal Reserve actions have their dominant inHuence on income, employment and prices, while Federal Reserve behavior is dominated by financial objectives, this will lead not only to increased instability in income, employment and prices, but also to increased instability in the long run for the financial system.

Michael W. Keran Christopher T. BabB

Two important issues not yet dealt with will be discussed in the following Appendix. Raising these issues earlier would have interrupted the development of the main body of the article.

\section{APPENDIX}

The present study, which relates the actions of the Federal Reserve to its objectives, differs from previous similar studies in two fundamental ways. First, the present study uses free reserves as a measure of the Federal Reserve's intent of policy with respect to its economic stabilization objectives, instead of relating the Federal Reserve's actions directly to its ultimate stabilization objectives. The use of free reserves as a proxy for the intent of economic stabilization policy, we feel, surmounts several serious structural problems which existed in earlier empirical models of Federal Reserve policy and actions.

Second, the present study relates Federal Reserve actions to a larger and more comprehensive set of Federal Reserve objectives than was previously considered relevant. In addition to the traditional economic stabilization objective with its output, price level, employment, and balance-of-payments dimensions, a case was developed in the text for the inclusion of even-keel and financial stability objectives.

\section{Various Approaches Relating the Federal Reserve's Objectives to Its Actions}

The use of free reserves as a measure of the Federal Reserve's intent of economic stabilization policy becomes more reasonable after an examination of previous studies of the Federal Reserve's behavior. We will consider such studies by Dewald and Johnson $(1963)^{1}$ and John Wood (1965).2 In addition, Christian's (1968) critique of the Dewald and Johnson article is also examined. ${ }^{3}$ No attempt is made in the following discussion to present

1See William G. Dewald and Harry G. Johnson, "An Objective Analysis of the Objectives of American Monetary Policy, 1952-1961," Banking and Monetary Studies," ed. Deane Carson (Homewood, Illinois: Richard D. Irwin, 1963).

John Wood, A Model of Federal Reserve Behavior, Staff Economic Study No. 17, Board of Governors of the Federal Reserve System.

James W. Christian, "A Further Analysis of the Objectives of American Monetary Policy," The Journal of Finance, volume XXIII, June 1968. 
a complete review of these articles. John Wood's model is considered first, because at first glance it appears to embody the ideal approach to studying the Federal Reserve's behavior.

\section{A Model of Federal Reserve Behavior}

Using the tools of micro-economic analysis, Wood de* velops a consistent model which connects an assumed FOMC disutility preference function to a policy model with economic structural relations. Within each of his model's structural equations, an adjusted first difference of free reserves is included as the Federal Reserve's intermediate financial target variable. The basic justification for this specification is that through its ability to affect free reserves, "the Federal Reserve conceives itself as infuencing the economy." + Yet, in spite of the theoretical sophistication of his economic model, the empirically based conclusions of Wood's study about FOMC behavior and policy add little to what was already known from much simpler models. The economic relations in Wood's model are such as to prevent him from "partitioning" the regression coefficients of his reducedform equation into the preference and structural parameters contained in his theoretical model.

The specification of Wood's contemporaneous structural model within the disutility framework made it impossible for him to disentangle the mixtures of "weights" and "effects" present in the reduced form regression coefficients. Whether or not these consequences might be remedied by an "appropriate" specification of time lags appears to be an unanswered question. The present study avoided the problems associated with "utility" functions through the use of free reserves as a summary measure of the intent of the FOMC's economic stabilization policy.

One implication of Wood's work appears to be that economists might profitably study the behavior of the Federal Reserve within the context of reduced-form models, involving time lags. This implication holds because the results of using fully specified structural models may be undecipherable. If appropriate time lags exist between actions and their impacts, reduced-form models can be set up where causation operates predominately in one direction. Such situations permit a relatively unambiguous interpretation of regression coefficients.

\section{A Reduced-Form Model}

In setting up our model of Federal Reserve behavior, we also benefited from an examination of some of the existing reduced-form models in this area. Specifically, an examination of certain problems inherent in Dewald and Johnson's reduced-form model guided us in the specification of our model.

Using the regression equation of the "reaction function" type, Dewald and Johnson (D-J) attempted to unearth two aspects of monetary behavior: (1) the relative importance of the various monetary policy objectives, and (2) the average lag period between a change in the "performance measure" of a policy objective and the response of monetary policy to that change. Related to 4Wood, p. 16. the latter goal of the study was an attempt to determine which indicator best measures monetary policy.

From an examination of the standard errors of their regression coefficients, Dewald and Johnson concluded that high employment and growth were the principal monetary objectives pursued by the Federal Reserve during the period of the study (1952-62). Also, when the money supply was used as the monetary policy variable, a long and possibly destabilizing lag of nine months was implied for the response of monetary policy to undesired changes in the economy. Nevertheless, they selected the money supply as the best proxy for monetary policy. Free reserves also provided acceptable statistical results.

\section{Weaknesses in the Approach}

Christian suggests that certain weaknesses existed in the D-J approach which would call their conclusions into question. Christian observed an instability in regression coefficients when the model was run for various overlapping subperiods contained within the total period used in the D-J study. "This finding raises a number of questions. Since each of the D-J regression equations fits within the framework of the Koyck distributed-lag model, the instability in the coefficients of their respective lagged dependent variables suggests that there is no simple average period of policy response. In addition, policy objectives which appeared to be very important in one regression period turned out to be insignificant in another. The latter result has two possible interpretations. First, the Federal Reserve's appraisal of its disutility associated with being off target for one policy objective may not be independent of how close other policy objectives are to their targets. Second, "instable coefficients" reffect a structural incompatibility among certain pairs of policy objectives which prevents their being achieved simultaneously through the use of one policy tool. Yet, even if policy goals are both independent and stable, regression coefficients may be biased in some indeterminate way as a result of insufficient variations in some of the "performance measures" of the economy, in either all or part of the regression period selected. ${ }^{5}$

Another problem with the D-J model is that the contemporaneousness of the policy function with the structural relations of the economy means that the coefficients of the D-J regressions are indeterminate mixtures of "effects" among the variables within the economy and "weights" of the respective "performance measures" within the Federal Reserve's preference calculus." The last-mentioned assumption of the D-I study (which also played an important role in John Wood's study) effec-

${ }^{5}$ Christian, pp. 465-477. In addition, the lack of consistency among the regression results for different periods may also reflect the exclusion of "performance measures" of policy objectives which are considered to be very important by the Federal Reserve. This problem was considered in the main body of the article and in the discussion of nonstabilization objectives.

"In his article "A Model of Federal Reserve Behavior," John Wood was perhaps the first economist who explicitly criticized Dewald and Johnson for failing to recognize this problem when they analyzed their regression results (see footnote 32 ). 
tively eliminated the possibility of drawing conclusions about policy preferences from the D-J reaction function model.

Dewald and Johnson attempted to achieve too much within the confines of a simple model. Basically, there are two problems with the D-s study which we feel were effectively eliminated from the present study. The first problem concerns the difficulties of relating the economic stabilization component of Federal Reserve actions to the ultimate economic stabilization objectives. The second problem is that of indeterminate mixtures of economic feedback "effects" and policy "weights" within the regression coefficients.

Relative to the first problem, instead of relating monetary policy directly to a set of stabilization objectives, the present study uses a single variable, free reserves, as a proxy for

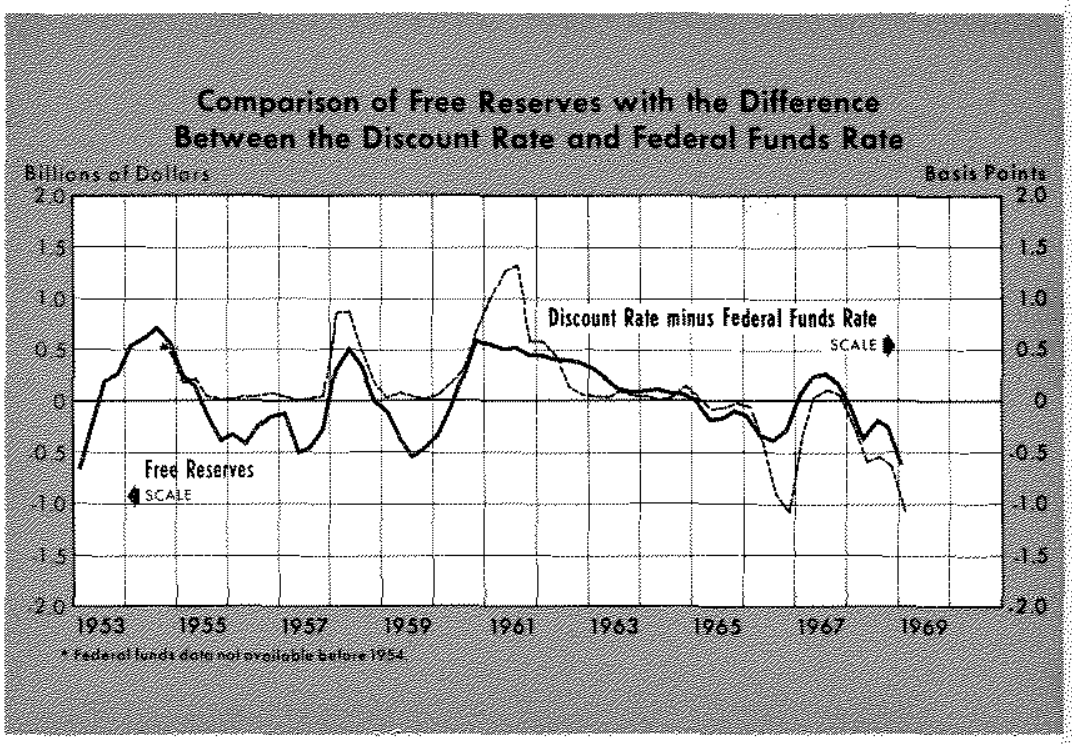
the Federal Reserve's intent of policy with respect to the economic stabilization objectives. The actual level of free reserves which indicates a certain degree of tightness or ease allows us to avoid the problem of measuring the tradeoffs between the various stabilization objectives.

Relative to the second problem, the present study arrived at a regression equation relationship between the three proxy variables of the Federal Reserve's objectives and the monetary base, which involves a one-way direction of causation due to the lag in the effect of changes in the base on total demand, as shown in other studies. With policy decisions and the proxy variables being predominantly influenced by the level of current economic activity, the coefficients of the regression equation appear to be fairly unbiased measures of policy weights.

\section{The Logical Consistency of Using Three Proxy Variables Within The Reduced-Form Equation}

In the process of setting up the reduced-form equation, the question arises as to the logical consistency of including the even-keel and financial stability objectives in the regression equation separately from the free reserves variable which, we argue, accurately reflects the net thrust of FOMC directives. This approach is reasonable because the open market desk operates in a context in which there is no rigid link between open market operations and the level of free reserves. That is, the Federal Reserve can control free reserves without changing its adjusted holdings of Government securities.

With its control of the discount rate, and its ability to buy and sell in the open market, the Federal Reserve has enough tools to achieve both a free reserves target and to carry on open market operations relative to its even-keel and financial stability objectives, quite independently of the free reserves contraint. This condition

serves as a justification for asserting that even-keel and financial stability objectives are not implicitly contained within the free reserves variable, but can be added to it in a regression equation which is used as an explanation of the movement in adjusted holdings of Government securities. If a rigid link existed between free reserves and open makket operations, then the trading desk could not achieve even-keel and financial stability objectives which were inconsistent with the desired free reserves target.

Given the existence of the profit motive on the part of the member banks, the movements in borrowing from the Federal Reserve, which are the dominant component of free reserves, could be induced by changes in the difference between the discount rate and the rate for alternative sources of funds, such as the Federal funds rate. In fact, we feel that there is substantial evidence which indicates that this difference does a satisfactory job of explaining movement in free reserves. In the above chart, the difference between the discount rate and the Federal funds rate is plotted along with the level of free reserves. The following regression equa* tion expresses the extent of that association:

$$
\begin{aligned}
& \text { IV/I954 to II/1962: } \\
& \mathrm{FR}=-0.23+0.83\left(\mathrm{RD}_{\mathrm{D}} \mathrm{R}_{\mathrm{F}}\right) \quad \mathrm{R}^{2}=.71 \\
& \text { III/1962 to IV/1968: } \\
& \mathrm{FR}=0.104+0.55\left(\mathrm{Rp}-\mathrm{R}_{\mathrm{F}}\right) \quad \mathrm{R}^{2}=.63 \\
& \text { (6.32) }
\end{aligned}
$$

where $\mathrm{Rp}$ is the Federal Reserve Bank of New York discount rate and $R_{F}$ is the Federal funds rate.

This mode of explaining movements in free reserves operates quite independently of the movements in the monetary base. The monetary base seems to be the best measure of "effective" open market operations after allowing for the Federal Reserve's defensive operations against the other source components of the base. Consequently, the monetary base can legitimately be regarded as an additive linear function of the separate proxies for the economic stabilization, even-keel and financial stabilization objectives. 